\title{
Are large fields of autumn wheat at Kvismaren, central Sweden, used as nesting and food search habitats by Skylarks Alauda arvensis?
}

\author{
Är stora höstvetefält vid Kvismaren i mellersta Sverige utnyttjade som bo- och \\ födosökshabitat för sånglärka Alauda arvensis?
}

\author{
JAN SONDELL
}

\begin{abstract}
The skylark Alauda arvensis population has declined in Sweden. The breeding in silage fields fails and the success in autumn crops is disputed. Therefore, I decided to study the skylark utilisation of autumn crop fields in Kvismaren, central Sweden. The largest accessible field was selected (40 ha) to get as tough conditions as possible for foraging. I could conclude that the nests were evenly placed, the youngsters developed normally and the occupancy was about 80 pairs or territories per $\mathrm{km}^{2}$. The skylarks searched for food as much inside as outside the large breeding field. The flight distances were on average $204 \mathrm{~m}$ and up to $550 \mathrm{~m}$. The conclusion was

\section{Abstract}

that autumn crops are probably as good as spring crops regarding breeding habitat; potentially even better as the offspring fledged at least 1-2 weeks earlier. One potential positive factor for the breeding was the occurrence of unsown tractor tracks (tramlines, $2.5 \%$ of the area) which were frequently utilised by the skylarks. Such tracks are commonly created nowadays in Sweden and may replace otherwise desired skylark plots.

Jan Sondell, Rulleuddsvägen 10, S-178 51 Ekerö. E-mail: jan.sondell@telia.com
\end{abstract}

Received 15 November 2016, Accepted 26 July 2017, Editor: Robert Ekblom

\section{Introduction}

The skylark is the twentieth most common bird species in Sweden. The population on farmland is approximately 680000 pairs with strongholds in provinces with the largest agricultural plains: Skåne, Halland, Västergötland, Östergötland, and Uppland (Ottosson et al. 2012).

Information mainly from England indicates that autumn or, as it often is called, winter crops are suboptimal breeding habitats for skylarks because of the height and density of the stems at breeding time. Vegetation grows too dense for the larks to move in and to use for foraging. Furthermore, large areas are sown with the same autumn crop and distances between the nest and potential foraging habitats may be too large. The mean foraging distance observed in southern UK was $75 \mathrm{~m}$ and only $10 \%$ of distances were longer than $150 \mathrm{~m}$ and the longest $380 \mathrm{~m}$ (Donald 2004).

The Common Birds Census in UK showed an almost "remarkable relationship" between the index for skylark abundance and area of spring crops during the period 1968-1996 (Donald \& Vickery
2000). The index went up from 0.6 at 1 million hectares spring crops to 1.3 at 2.5 million hectares. This striking correlation has put focus on negative consequences when autumn crops replace spring crops. A possible method to improve the habitat for skylarks is to leave small unsown areas in the field (so-called skylark plots), normally two per hectare with an area of 16-24 $\mathrm{m}^{2}$ (RSBP Leaflet: Skylark plots).

Morris et al. (2004) showed that two undrilled plots of $24 \mathrm{~m}^{2}$ per hectare were not related to the skylarks' nesting success at the beginning of the breeding season: he found 1.27 fledged nestlings without plots vs. 1.31 with plots. Later in the season, when the crop had grown high, the effect of the plots was significantly positive; the number of nestlings was 0.87 per nesting attempt in areas without plots compared to 1.86 in areas with plots.

In Sweden Hiron et al. (2012) found that skylarks utilised autumn crops as breeding habitat as much as spring crops, and Berg \& Kvarnbäck (2011) found no difference in population density in organic autumn crops with and without skylark plots. 

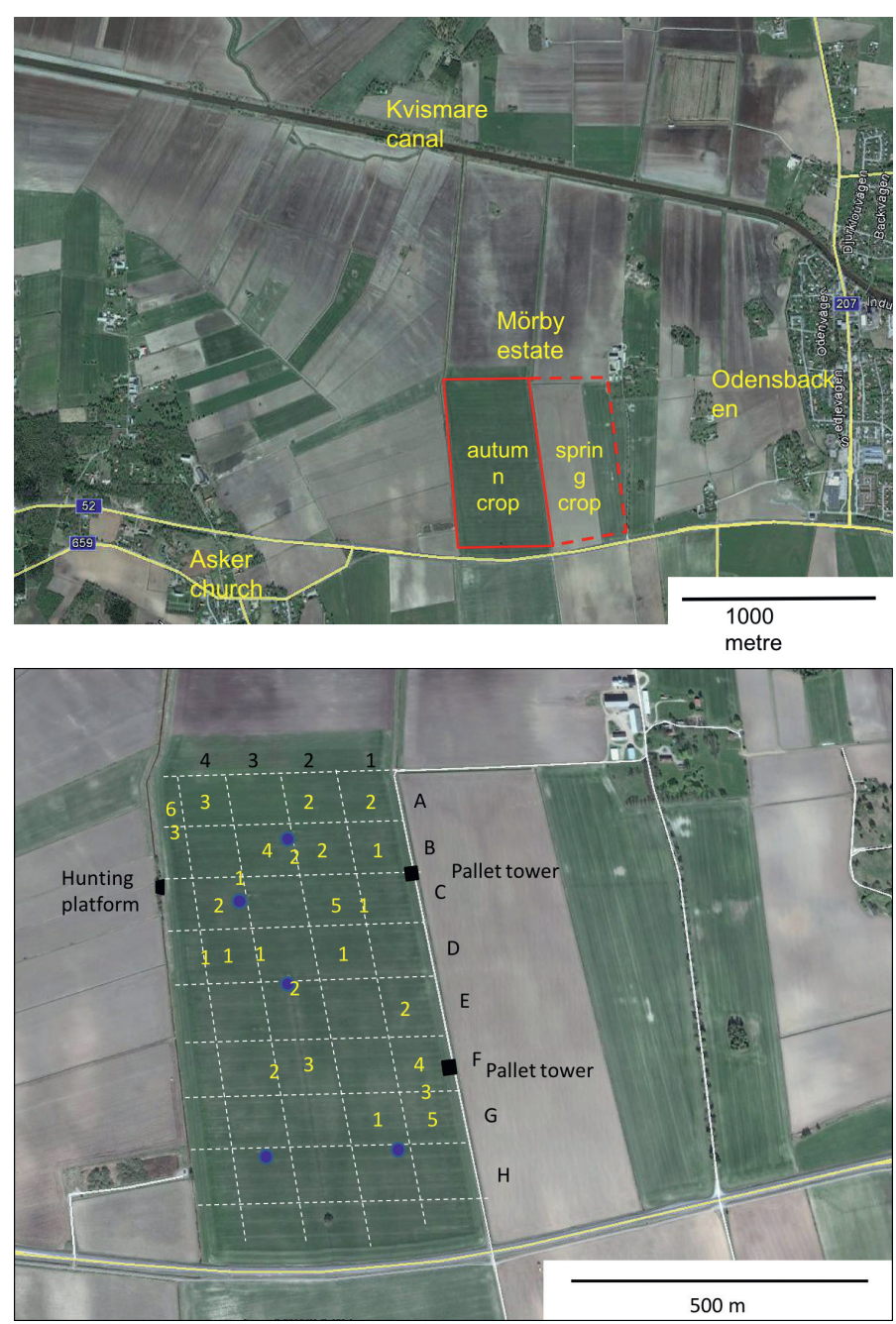

Figure 1. Study area between Asker and Odensbacken, Örebro commune, central Sweden. The main study field is bordered by solid red lines. A spring crop area used for some comparisons next east of the main study area is bordered by dashed red lines.

Studieområdet mellan Asker och Odensbacken i Örebro kommun. Den huvudsakliga studieåkern är markerad med heldragen röd ram. En vårsådd åker, som användes för vissa jämförelser omedelbart öster därom, är markerad med streckad röd ram.

Figure 2. The study field at Mörby estate with observation towers (black squares). Number of observed foraging trips related to nests in different grid cells are indicated by yellow numbers. About 20 nests were estimated to be involved in the study. Blue dots are water regulation wells. Note the pond covered with reed containing a marsh harrier nest south-west of the field (close to square H5).

Studiefältet på Mörby gård med observationsposter (svarta fyrkanter). Antal observerade födosök relaterat till bon i indelade rutor anges med gult. Ca 20 bon bedömdes ingå $i$ studien. Blå fläckar är brunnar för vattenreglering. Ett kärrhökbo låg $i$ en vasstäckt damm alldeles utanför ruta $\mathrm{H5}$.
Odderskær et al. (1977) studied the skylarks' utilization of micro-habitats in spring barley fields and found that unsown small patches and tractor tracks were preferred compared to areas with uniform swards. Schön (2011) is more hesitant to endorse "artificially created" skylark plots and says that there are permanent structures in the fields which may develop spontaneously and exist over long time. These are highly appreciated by the territory-faithful skylarks.

In 2015 we studied the density of skylark territories in 50 ha of silage fields, 110 ha of spring crop and 40 ha of autumn crop in the Kvismaren valley (Sondell et al. 2016). We found about the same density (75-83 pairs per $\mathrm{km}^{2}$ ) for the different crops. Important to know in this context is that skylarks are very faithful to the territory held the previous year (Delius 1965, Jenny 1990, Donald 2004). As far as we understood the skylarks nesting in the grain crops developed well but skylark nests in silage fields were destroyed by the harvest. It would be interesting to understand what happens in autumn crops in Sweden. Are there similar problems relating to the dense vegetation as indicated by the studies in England (Morris et al. 2004)? The search for food is probably most difficult in large fields with high uniform vegetation where the borders of the field, i.e. potential foraging areas outside the field, are far away.

The 2016 skylark studies at Kvismaren were aimed to learn about skylark breeding in large homogenous fields of autumn crop: where do the larks 
place their nests, is the breeding successful (mainly in terms of active feeding behaviours), and how far do they fly to find food to feed the nestlings?

\section{Study field and study conditions}

The Kvismaren valley is a wide agricultural plain in central Sweden situated about $15 \mathrm{~km}$ SE of Örebro in the province of Närke. To locate a very large homogenous field for the studies in this area Google earth maps were used. Three suitable fields with autumn crop were found. We chose a wheat field at Mörby estate between Asker and Odensbacken. The field measured $450 \times 900 \mathrm{~m}$, thus with an area of about 40 ha (Figure 1).

The selected field was one of the largest in the province of Närke 2016 and according to estimations made using Google earth it belongs to the largest category in Sweden. Arable fields in Sweden, even in plain areas, are usually divided into smaller cultivation units by farm roads or ditches, clearly visible on an aerial map. The study field is bordered by the county highway 52 in the south (Figure 1 and 2). East of the field is a gravel road and an open ditch. Another similar field next to the east border was sown with spring barley and the field north of our study field with spring wheat. West of the field is a quite large ditch, and on the other side several smaller fields, most of them with spring crop. The autumn crop at the study field was accordingly more or less surrounded by spring crop. We concentrated our observations to the central and northern part of the field, as skylark activity was estimated to be lower in the southern part, possibly due to disturbance from the road. The spring crop field east of the study field was partly used as an area for comparison of crops growth, nest period and stay after breeding.

In the study field there were five water regulation wells clearly visible on the map and in the terrain (Figure 2), which facilitated distance orientation. A $2 \mathrm{~m}$ high hunting tower was already located at the field edge, and a further two 1.5-2 m high observation towers were built using pallets (Figure 3 ). Thus three observers could work simultaneously from different places. We also put up sticks $100 \mathrm{~m}$ apart along the gravel road $(\mathrm{A}-\mathrm{H})$ and the northern border (1-4) marking endpoints of gridlines across the field (Figure 2) to further facilitate orientation.

Only one solitary big oak was within the study field in the south and a row of 5-8 $\mathrm{m}$ high broadleaved trees or bushes were found at the north-western side together with the larger ditch (Figure 2). In the uniform study field there were a few $(\leq 5)$ small

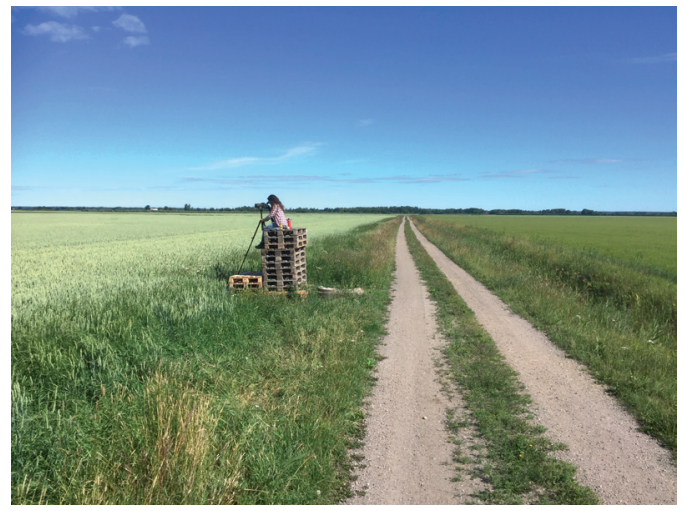

Figure 3. Southern pallet tower along the gravel road. Mariana Lapa is searching for nests. Autumn wheat to the left and spring barley to the right.

Södra utsiktsplattformen vid sök av lärkbon. Höstvete till vänster och vårkorn till höger.

(approx. 10 sq.m.) unsown patches, probably created by some problem with the sowing machine. On some areas the weed couch grass Elymus repens was common and covered the ground. However, the total area with this weed was less than one hectare.

In the study field unsown tractor tracks (called tramlines in the UK) were present. The field had been sown with a Väderstad Combi Rapid sowing machine. A GPS steering device was used with RTX support (Real-Time eXtended) to keep the tracks straight and make them possible to maintain throughout the season. The equipment produced two unsown tracks every $24 \mathrm{~m}$ apart by leaving two unsown rows at $0.125 \mathrm{~m}$ distance for each tractor wheel (total theoretical width $0.375 \mathrm{~m}$ ). The rubber tyres were $0.30 \mathrm{~m}$ wide (Figure 4), i.e. there were $0.3 \mathrm{~m}$ wide tracks twice every $24 \mathrm{~m}$ all over the field resulting in an area share of approximately $2.5 \%$. On each passage the existing tracks were somewhat widened, and the weeds on the ground together with some crop stems were pressed down by the wheels at the track edges, becoming compressed (Figure 4). The field was fertilized four times starting on 20 April and sprayed once each with herbicides (against weeds) on 29 April and with fungicides on 15 June to fight crow rust Puccinia coronate and filamentous fungus Mycosphaerella graminicola. The last passage was on 15 June. Hence, a tractor passed over the field a total of six times before the end of June. In the spring crop there were also tramlines and several tractor passages. 


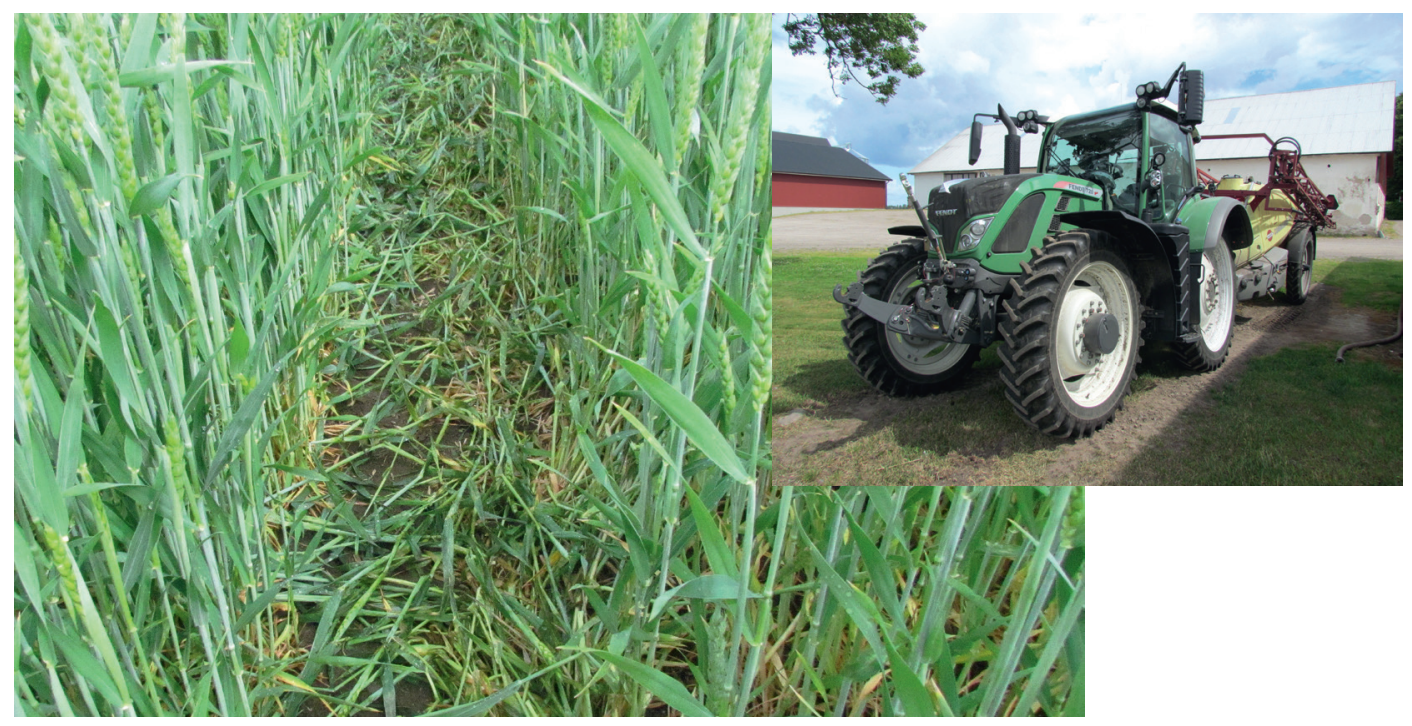

Figure 4. Unsown tractor track on 16 June after the sixth tractor round 15 June 2016. Note the unsown ground and some compressed straws of wheat from the sides of the row. The smaller image shows the tractor with trailer.

Osått traktorspår 16 juni efter den sjätte traktorpassagen 15 juni 2016. Notera den osådda marken och några från radens sidor nerpressade strån av vete. Lilla bilden visa den aktuella traktorn med vagn.

\section{Methods}

\section{Skylark observations}

In total, approximately 80 man-hours of observations in the autumn crop were carried out during 17 days between 30 May and 19 June 2016, thus 17 out of 21 available days. This period was chosen to begin when we judged the skylarks to have started intensively feeding the chicks and ended when no more nest feeding activities were going on.

The height of the crop in the wheat field was measured by holding a one metre long stick horizontally at the top of the stems and then measuring the distance to the ground. The measurements were done on 10 days during the period 30 May-30 June, measuring five representative height values and calculating a mean per day.

A main interest was to estimate and record approximate nest locations, the distances between nest locations and foraging sites, and the type of foraging habitat chosen. At first skylark nests in the autumn wheat with active feeding during an observation shift were observed. After about three foraging trips an exact direction (using a spotting scope) and an approximate distance to the nest was recorded. The distance estimate was facilitated by subtle variation in the vegetation along the actual direction. Each foraging trip was characterised as on one of the following:
A complete foraging trip including starting a flight from the nest for search and returning with food in the bill to the nest.

A flight out from the nest ending with a drop to the ground in a foraging area or a skylark just leaving to disappear out of the foraging area (flying out from the same area several times).

A flight back from the foraging area to the nest with or without visible food in the beak. This mostly happened at shorter foraging distances.

That feeding had taken place was demonstrated by a lark landing in the vicinity of the nest with food in the beak and a lift out from the nest position afterwards, very often with a visible dropping in its bill. Many larks landed a small distance away from the nest on small open patches, see Appendix 1. A foraging trip lasted often up to 20-40 minutes on the ground searching for food and birds spent $1-5$ minutes at the nest when feeding the young. After about 40 minutes of not seeing any lark we regarded the bird as lost.

We also visited 6 nests, selected at random, to check the nests' condition and offspring development. The selected nests had different distances to the field edges.

To find out where skylarks gathered at the end of the first clutch breeding period we searched both fields (autumn wheat and adjacent spring barley, 
Figure 1) by walking the unsown tracks to flush skylarks on 23 June, starting 0800 and ending 1600. Two people (ML \& MP) spent a whole day walking $35 \mathrm{~km}(2 \times 17.5 \mathrm{~km})$ and searched for skylarks. The search started with tracks close to and along the gravel road and continued successively farther away from the road (Figure 2). During this search we also recorded singing skylarks that would indicate territory claiming for starting up a new clutch.

All possible nest predators passing over or close to the study field were recorded during all observations of skylarks.

\section{Ground dwelling invertebrates}

At Kvismaren a study of Ortolan Bunting Emberiza hortulana has been going on since 2009. With the intention to examine supply of food for that species in agricultural landscapes, a study was carried out in 2012 with collection of ground dwelling invertebrates in different foraging habitats. These invertebrates are also the main food for skylarks.

Presence of ground invertebrates was surveyed using pit fall traps that consisted of plastic cups (height $100 \mathrm{~mm}$, width $70 \mathrm{~mm}$ ) dug down to the ground surface and filled at the bottom with some water containing detergent. We used 5 traps within some 25 sq. m. each in 5 different habitat types (in total 25 traps): (1) unsown field (set aside), (2) a 2 m unsown strip along spring crop field, (3) at the shoulder of the gravel road, (4) oat field, and (5) potato field. The trap sites were situated in a similar part of the Kvismaren valley about 5 and $6 \mathrm{~km}$ from the study field of 2016. There were 3 collection rounds, on 18-22 May, 6-10 June and 24-28 June. The results are briefly presented here as they are relevant for the discussion of the food search of the skylarks.

\section{Tractor tracks in Swedish autumn crop}

In order to collect information on the occurrence of pre-prepared tractor tracks in Swedish grain fields, a $500 \mathrm{~km}$ car drive was carried out on 1 August 2016 through the provinces of Sörmland, Närke, Västmanland and Uppland. All grain fields bordering the road were checked for presence of tractor tracks of different kinds (pre-prepared or created when fertilising or spraying). The harvest of autumn wheat (and triticale) was just about to start.

\section{Results}

Crop height

In the study field the wheat stems grew from $0.45 \mathrm{~m}$ on 30 May, $0.75 \mathrm{~m}$ on 13 June, $0.80 \mathrm{~m}$ on 19 June and to $0.90 \mathrm{~m}$ on 30 June. The spring barley next to the main study field was about $0.2 \mathrm{~m}$ lower on 30 June.

\section{Distribution of nest in the study field}

A compilation of the grid cell nest notations is shown in Figure 2. Judged by this about 20 nests were involved in the study, during one or several days. The figure also shows that the nests appear to be randomly spread in the northern and central part of the field. However, in the south and south-western corner with no observation tower and closer to the highway, few or no nests were observed or searched for. No clear aggregation of nests is apparent, neither along the borders of the field or in the centre.

\section{Visited nests}

We visited randomly selected nests, three nests in autumn crop (calculated start of egg laying: 18, 21 and 23 May) and three in the adjacent spring crop (calculated start 13,17 and 19 June) to check nest condition and development of the young. All nests had been built on flat ground in the crop a small distance away from unsown tractor tracks. Not far away from most nests we often found small patches of open ground (Appendix 1). The mean number of young was 3.66 and the nestlings were 6-9 days old. All clutches appeared to be developing normally. When approaching the nest, the young first hid in the nest cup but when disturbed and handled they were quick to try to escape.

Utilisation of tractor tracks, perches in the field and farm roads

Many of the larks were observed to use the unsown tractor tracks when they were landing in the field, both to forage and to deliver food to the nest (Appendix 2). Early in the season, when the crop was not so high and the tracks therefore were not so distinct it was hard to see if the larks were using the tracks to land. But later in the season when the crop got higher and denser it was obvious that the tracks were utilised (Figure 5). The field was both fertilised and sprayed 15 June by use of a tractor going twice in the tracks. During the passage the tracks were somewhat widened by the wheels through pressing down of some vegetation (Figure 4), which might be of sig- 


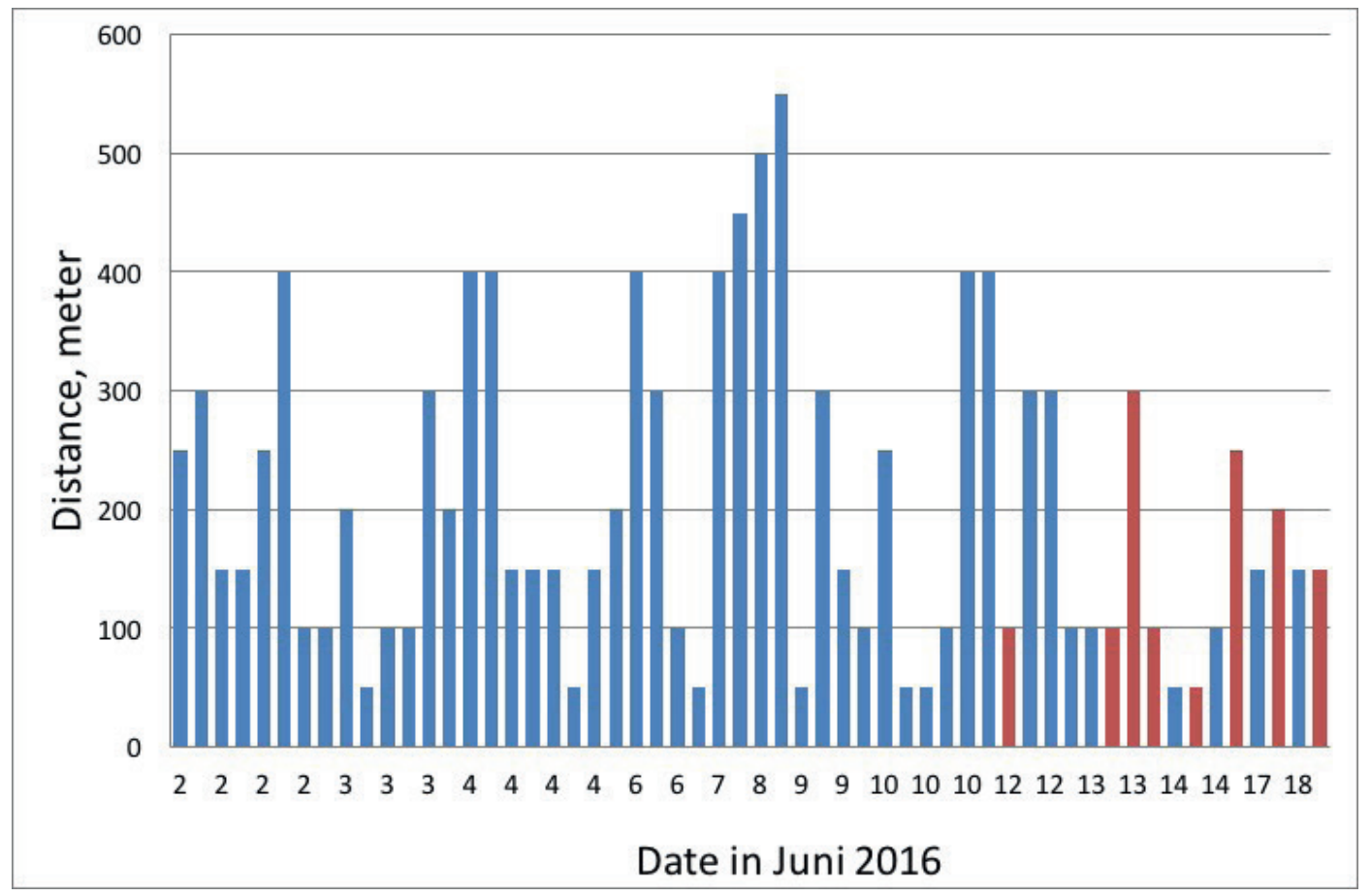

Figure 5. Estimated distances for food search during June 2016. Red bars indicate use of tractor tracks. Uppskattat avstånd för födosök olika dagar i juni 2016. Röda staplar indikerar utnyttjande av traktorspår.

Table 1. Number and biomass of invertebrates collected in 2012 with pit fall traps (plastic cups) dug down to ground surface in five different farmland habitats ( 5 pitfall traps in each) in the Kvismaren valley.

Antal och vikt för ryggradslösa djur fängade $i$ Kvismaren 2012 med fallfällor (plastglas) nergrävda till markytan, fem fällor $i$ vardera av fem olika habitat.

\begin{tabular}{|c|c|c|c|c|c|c|}
\hline $\begin{array}{l}\text { Catching round } \\
\text { Fångstomgång }\end{array}$ & $\begin{array}{r}\text { Unsown } \\
\text { field } \\
\text { Osått fält } \\
\end{array}$ & $\begin{array}{r}\text { Unsown } \\
\text { edge } \\
\text { Osådd } \\
\text { åkerkant } \\
\end{array}$ & $\begin{array}{r}\text { Shoulder of } \\
\text { gravel road } \\
\text { Vägkant, } \\
\text { grusväg } \\
\end{array}$ & $\begin{array}{r}\text { Spring } \\
\text { crop, oats } \\
\text { Vårsäd, } \\
\text { havre }\end{array}$ & $\begin{array}{r}\text { Potatoes } \\
\text { Potatis }\end{array}$ & $\begin{array}{r}\text { Sum } \\
\text { Summa }\end{array}$ \\
\hline \multicolumn{7}{|l|}{ Round 1, 18-22 May Omgång 1} \\
\hline Number of individuals Antal individer & 163 & 82 & 372 & 121 & 70 & 808 \\
\hline Weight in grams Vikt i gram & 8 & 8 & 6 & 4 & 11 & 37 \\
\hline \multicolumn{7}{|l|}{ Round 2, 6-10 June Omgång 2} \\
\hline Number of individuals Antal individer & 61 & 48 & 125 & 81 & 154 & 469 \\
\hline Weight in grams Vikt $i$ gram & 5 & 6 & 9 & 9 & 13 & 42 \\
\hline \multicolumn{7}{|l|}{ Round 3, 24-28 June Omgång 3} \\
\hline Number of individuals Antal individer & 69 & 61 & 132 & 65 & 70 & 397 \\
\hline Weight in grams Vikt $i$ gram & 8 & 9 & 8 & 7 & 7 & 39 \\
\hline Sum; individuals Summa individer & 293 & 191 & 629 & 267 & 294 & 1674 \\
\hline Sum; weight in grams Total vikt $i$ gram & 21 & 23 & 23 & 20 & 31 & 118 \\
\hline
\end{tabular}


nificant importance to the larks' activity. Small open patches, due to irregular sowing for example, also occurred near nesting places (Appendix 1). Furthermore, at each water regulation well in the study field a small marker sticks could be found. These sticks were used by the birds for perching and also to sing. Several observations were made of birds using the water regulation well areas to land on the field both to access the nest and to forage for invertebrates.

The gravel road to the east was used as a resting (mainly in the afternoon, see "Flush study") and foraging area, particularly after the young had fledged and breeding was about to cease in the autumn crop field. A grassy farm road bordering the study field in the north was used for foraging, particularly at the end of the breeding period when the spring crop was also quite high.

\section{Foraging behaviour and distance}

During the period 30 May-19 June a total of 84 foraging trips were recorded (presented in detail in Appendix 2). For 61 of the foraging trips we could identify specific foraging places. Skylarks searched for food both within and outside the autumn crop to about the same extent (Appendix 2). Of the observed foraging places, $27(44 \%)$ were situated within the wheat field and $22(36 \%)$ in surrounding spring crop, and the remaining $20 \%$ outside along the farm roads. Regarding the outside foraging places, two were observed for skylarks finding food on the gravel road and 10 in the grass on a farm road at the northern border of the study field.

The unsown tractor tracks were used in the later part of the nesting season (Figure 5, indicated by red bars). Over the period 30 May-19 June the nest feeding activities in the autumn crop gradually decreased with date. After 13 June when the swords reached $0.75 \mathrm{~m}$ in the autumn wheat field a higher share of the larks was observed in that field in and around the tractor tracks (Figure 4). (The spring crop had at that time also grown fairly high.)

The estimated foraging distances in June varied from finding food close to the nest up to $550 \mathrm{~m}$ (Figure 5). The mean foraging distance in our study was $203.6 \mathrm{~m}, \mathrm{SD}=70.7 \mathrm{~m}, \mathrm{~N}=56$. Out of the observed foraging trips, $13(22 \%)$ were estimated to be over 300 $\mathrm{m}$ with the longest being $550 \mathrm{~m}$.

\section{Invertebrates}

Skylarks feed on small invertebrates found on the ground or in the ground vegetation (Smith et. al 2009). A total of 1674 individuals of ground dwell- ing invertebrates, with a total weight of 118 grams, were identified using pit fall traps (Table 1). The abundance and biomass of invertebrates was moderately varying between habitat types and over time (Table 1). The number of individuals decreased from collection round 1 to round 2 and 3 , mainly at the roadside habitat. The biomass expressed by weight varied between habitat types from 21 to 31 gram.

\section{Flush study}

In total 35 skylarks were observed during the flush study on 23 June (after the first clutch had fledged). In total 5 larks were flushed from the autumn crop and 8 from the spring crops. All larks were flushed from the unsown tracks in both fields with some droppings also being found in these open rows. Between the tracks additional larks may have dwelled, but remained unflushed, as the tracks were specifically used as walking paths during flushing. In addition, 10-13 skylarks were seen actively flying over each field. The activity of the skylarks decreased after midday and many were seen resting by sitting on the gravel road. Six birds were flushed by the car there when leaving the area. As the fields are of equal size (about $40 \mathrm{ha}$ ) the figures are comparative. During the flush study on 23 June no skylark song was heard in the area (during 8 hours of field work), indicating that territories for a second (or replacement?) clutch were not defended at that time.

\section{Predators}

Only one observation of an attempted predation event was made. It was a marsh harrier Circus aeruginosus unsuccessfully tried to catch a skylark. However, several potential predators were seen foraging in the field, such as fox Vulpes vulpes, marsh harrier, short-eared owl Asio flammeus, hooded crow Corvus corone cornix, jackdaw Corvus monedula, kestrel Falco tinnunculus and hobby Falco subbuteo. A pair of marsh harriers were breeding in a pond close to the SW corner of the field (visible in Figure 2), and a hooded crow was seen several times perching in the southern tower. The two latter species were observed on a daily basis. No smaller mammals such as hedgehog, ferret, weasel, mink, cat, etc. were observed in or even in the vicinity of the study field.

\section{Tractor tracks in fields of central Sweden}

Today the share of sowing machines having the function to leave rows unsown in conventional farming is estimated to be approximately $90 \%$ (Lennart Kars- 
son, senior service supervisor at Vaderstad Ltd.). The car survey on 1 August 2016 showed that about $75 \%$ of the surveyed grain fields along the highways had tractor tracks. Fields without tracks were mostly organic fields, spring oats and spring barley fields. Almost all wheat fields had tracks, both autumn and spring wheat. In most autumn sown fields, the tracks were unsown and were clearly visible. There were also some spring wheat fields where green grain grew in the tracks indicating that no unsown rows had been prepared in advance.

\section{Discussion}

\section{General}

The skylark dominates the sky over open agricultural plains. This species is independent of song posts and avoids all forest edges and tree islets (Piha et al. 2003). It is the only common bird species in Sweden dedicated to wide open farmland. The skylark is an excellent flyer. In spring the male claims territory by singing for hours (Donald 2004). No other bird utilises uniform arable land to the same extent. It avoids fields smaller than about 10 ha (ca. 325 times $325 \mathrm{~m}$ ) and chooses nest places at least 100-200 m from forest edges (Piha et al. 2003).

In 2014 grassland covered 45\%, spring crop $23 \%$ and autumn crop $17 \%$ of the farmland area in Sweden (Jordbruksverket). The skylark is faithful to its breeding site from previous year (e. g. Delius 1965). Independent of the farmer's cultivation intentions of the actual spring the faithfulness is strong. If it is silage the whole reproduction of the year will be spoiled (Jenny 1990, Sondell et al. 2016). Autumn crop is also a crop that has been disputed. Is it good or bad for the larks? Do skylarks have difficulties reproducing in this type of crop that tends to be both high and dense? Results from England clearly indicate that autumn crop is too high, too dense and covers too cohesive an area. Measures there are thus necessary to maintain the population (Donald \& Vickery 2000, Morris et al. 2004)!

\section{Distribution of nests, foraging behaviour and distance}

We estimated that around 20 skylark nests were active in the northern, central and eastern part of the field (Figure 2). The density of nests was thus of the same magnitude as in the territory studies 2015 (about 80 territories per $\mathrm{km}^{2}$, Sondell et al. 2016). These data indicate that the large uniform area did not at all restrain the larks from breeding (Figure 2).

The study result shows that search for food at distances over $300 \mathrm{~m}$ was regular (mean distance at least $204 \mathrm{~m}$ ) and up to $500 \mathrm{~m}$ was not uncommon (Figure 4), and that the larks searched for food both within and outside the autumn crop to about the same extent (Appendix 2). As there are very few fields suitable for autumn crop with areas larger than our study field practically all fields in Sweden are available for nesting by skylarks being able to search for food outside the field. Our study field was, as mentioned, among the largest in the province of Närke, and the situation is almost the same in other provinces according to Google earth. As the skylark population was relatively dense in the actual field (about 80 pairs per ha) the reproduction is obviously normal despite long feeding distances.

\section{Tractor tracks}

We noticed that when the crop grew higher the unsown tractor tracks played an increasingly important role as resting and food search habitat. In the study field these tracks covered about $2.5 \%$ of the total area. Another positive effect is that the tracks hosted a limited amount of weed at the ground, probably because of the shade and the compression from the tractor wheels (Figure 4). Weed may sometimes grew very dense where there is enough sunlight (and water supply which varies over time and years with the precipitation) and could potentially prevent the skylarks from finding invertebrates at the ground.

Negative effects of the tracks may be that they serve as corridors for smaller mammalian predators. Predator pressure was judged to be low in the study area. The visited nests were placed well off the tracks except one lying right between the two wheels. Nests placed in the actual tracks will be destroyed by the wheels early in the season.

\section{Abundance of food}

The study conducted with pitfall traps in the Kvismaren valley 2012 shows that there are plenty of invertebrates, independent of type of farming habitat. Therefore, the main question is whether the invertebrates are accessible for the skylarks or not (Menz 2008). The food is easier to catch on open ground or in low grass along roads, on open patches in the fields and along the tractor tracks when the crop stems grow higher. In areas of dense vegetation, the food is more difficult or impossible to extract. Our data indicate that there is food every- 
where, but critical for foraging success is to find a foraging area where it is possible to extract.

\section{Breeding period and number of clutches}

The issue about how many successful clutches the skylarks produce and its relative contribution to the production of young in a specific year is crucial for the long term population development of the species.

A breeding cycle covers about 45 days including (re)start with nest building (Donald 2004, Sondell et al. 2016). After 26 days it is possible to ring the young. The first ringing takes place in central Sweden during the last few days in May when the young are about 6 days old (data from the Swedish Bird Ringing Centre analysed by Sondell et al. 2016). Thus the breeding starts with nest building on average 1 May, egg laying around 5 May. A second clutch is possible and it will start around 15 June and end 30 July. More likely than a true second clutch a first failed clutch is followed by a replacement clutch. See Figure 6 for a sketch on the timing of the breeding cycle. In spring crop the start of breeding is delayed compared to autumn crop until the growing crop hides the nest as no nests are placed on open soil.

The issue about number of clutches can also be elucidated by the 2015 studies at Kvismaren (Sondell et al. 2016). In the large silage field (50 ha housing about 40 pairs) all nests were destroyed on 8 and 10 June by the harvest. An inventory on 7 July showed 0.31 and one on 17 July 0.17 song territori- es per hectare compared to 0.83 per hectare in May. Although the larks had got the nest destroyed when having only half grown youngsters in the nests their willingness to start a replacement clutch was low. Most probably only part of the $20 \%$ (theoretically 8.5 pairs) that were singing again on 17 July fulfilled a replacement clutch.

To understand the timing of breeding it is also essential to know the start and length of the moult period. The period of primary moult for skylarks in England is 60 days (in Lincolnshire; Davies 1981) or 58 days (Ginn \& Melville 1983) and starts, as for most passerines, directly after breeding in July and ends in the middle of September. No moult data on skylarks is accessible from Sweden but a common species at Kvismaren living in the same farming areas is the yellowhammer Emberiza citrinella. The moult periods are fairly compatible. Its primary moult is of the same length as for skylark, or 58-60 days in England (Ginn \& Melville 1983) and in Sweden, a complete wing moult (primaries and secondaries) is carried out in 67 days (611 birds studied 1976-2015, Kvismare Bird Observatory, unpublished data). The yellowhammer moult at Kvismaren starts on average on 18 July and is finished around 25 September. (Later in the year if access to invertebrates for building new feathers is scarce.) According to the accessible data only a minority of the yellowhammers are able to start a true second clutch in the middle of June as it will not be finished until the end of July. The timing agrees with that of the skylark (Figure 6).

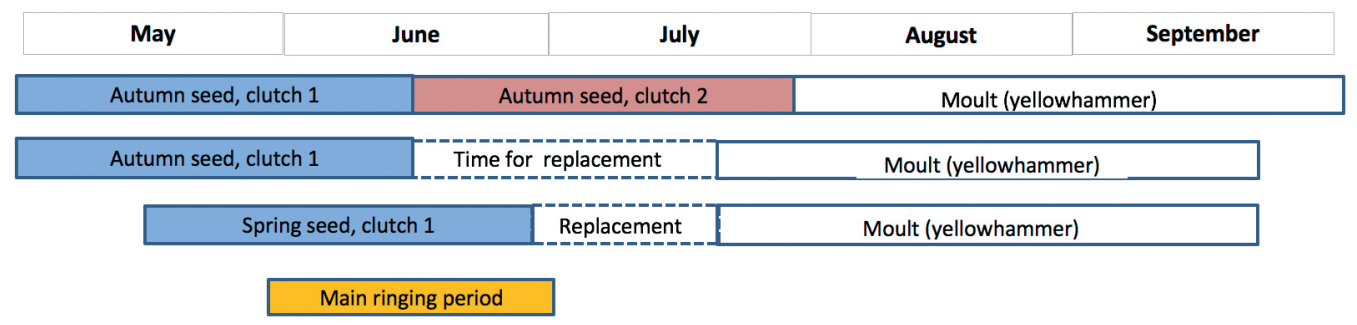

All ringing period

Figure 6. Schematic view of timing of breeding and moult for skylarks in Sweden. Nest building, egg-laying, incubation and feeding young takes about 45 days. The period for moult is assumed to be identical with that of the yellowhammer, which is 67 days. Ringing periods for skylark nestlings according to Swedish Bird Ringing Centre.

Principskiss över tidsåtgången för sånglärkans häckning och ruggning $i$ Sverige. Bobyggnad, äggläggning, ruvning och ungmatning tar ca 45 dagar. Ruggningsperioden som antas vara densamma som hos gulsparv är ungefär 67 dagar. Ringmärkningsperioderna för boungar av sånglärka är härledda från Ringmärkningscentralens data. 


\section{Timing of breeding}

As discussed above the reproduction of skylarks in Sweden mainly relies on the output from the first clutch as for most other passerines (Sondell \& Schilt 1985, Sondell 1987, 1993, 2000, Sondell \& Nielsen 2015). A second clutch is, as discussed above, less likely in Sweden. Most passerines have only one clutch. Judged from the moult card archive at Kvismare Bird Observatory (13 000 cards 1973-2016) and so far published data, they have time only for a replacement clutch if necessary (Figure 6). UK reports on skylarks suggest that the skylarks frequently produce several clutches each year, probably because the predation pressure from small mammal predators is high, and replacements are regular (Morris et al. 2008, Buckingham et al. 2015). At Kvismaren the predation risk is probably lower and is mainly caused by birds (harriers, crows etc.) as in the Czech Republic (Praus et al. 2010). Some nests may possibly be damaged by the tractor wheels in unsown tracks.

The skylarks started to breed earlier in autumn crop, compared to the spring crop adjacent to our study field (median ringing date for our three nests in autumn crop was 13 June and for three nests in spring crop 7 July), as the plants there were able to hide a nest earlier in spring. From a temporal point of view, autumn crop is thus preferable as breeding habitat compared to springs crop, as the young may become independent at least 1-2 weeks earlier (Hiron et al. 2012, Sondell et al. 2016). In the summer of birth, the skylark young will carry out a complete moult of body, wing and tail feathers. The earlier such a moult takes place the better, as the feather growth is dependent on nutrients from invertebrates (protein). There are also many studies stating that passerines starting the breeding cycle earlier have higher reproductive success in terms of fledged young, e.g. Perrins (1970).

\section{May unsown tractor tracks replace skylark plots?}

The technical function to leave tracks unsown was first marketed by Väderstad AB (Vaderstad Ltd) in 1984-1985, the biggest manufacturer of sawing machines in Sweden with a market share of about $80 \%$ (Lennart Karsson, senior service supervisor at Vaderstad Ltd). This function has successively been more and more adapted by the farmers, by getting both new sowing equipment and more sophisticated steering devices (GPS/RTX). Previously the tractor wheels only depressed the stems, and depending of number of passages and the date during the growing season, the plants more or less recovered. The recovery was delayed as the stems in the tracks matured later and were often still green at harvest time. To harvest green grain increases the moisture content of the crop and increases the drying cost. Therefore, unsown tramlines have gained terrain in later years. Today most tracks in autumn crop in central Sweden are unsown.

The solution in the UK to support skylark reproduction was to create skylark plots, recommended by RSPB to cover about $0.5 \%$ of the fields to improve the foraging habitat. The skylark plots are promoted by saying that the breeding output doubles, but this is true mainly in the later part of the breeding season. For early clutches the lark plots make little difference (Morris et. al 2004). In Sweden the first clutch is (as argued above) most significant for the reproductive output.

The crop is probably lower and less tight in Sweden compared to England, and autumn crop covers only $10-25 \%$ of the total farmland area, varying between regions and years (Jordbruksverket). The unsown tractor tracks in the study field covered an unsown area five times larger than that recommended for lark plots and these tracks were also evenly distributed over the field. Furthermore, lark plots more often get covered with weed because they are exposed to more intense light at ground level, in comparison to the tractor tracks (own observations).

Later in the season when the crop had grown higher, we observed that the tracks were frequently used (Figure 5), probably both for feeding, resting (flush study) and to get easy but hidden access to the nests. The study therefore indicates that skylark plots may not be needed at all on farmland in Sweden where nowadays unsown tracks are present in most fields.

Resources today earmarked for conservation of skylarks are in my view put to best use in efforts to reduce the disastrous loss young of skylarks, and many other farmland bird species, when harvesting silage fields (Sondell et al 2016). More research is needed to find the best methods to do this.

\section{Acknowledgements}

The field observations were mainly performed by Mariana Lapa (ML), Magnus Persson (MP) and Stanley Tang (ST), many thanks to them. I also thank entomologists Ruth Hobro and Gunnar Sjödin, Ekolsund, for their careful examination of invertebrates. Johan Bergstedt and Mattias Sundin welcomed us to carry out the study at Mörby estate 
and lent us the pallets. Kvismare Bird Observatory lodged the field workers. A special thanks to Lei Stanley Tang for the information on nest location, to Julie Murray for checking the language of an earlier version of the manuscript, and to Debora Arlt who has checked both content and language of the final version. Örebro läns landsting has financially supported the study. Mariana Lapa has also provided many valuable comments on the manuscript. Excuse for disturbing your thesis work!

This is contribution No. 181 from Kvismare Bird Observatory.

\section{References}

Berg, Å. \& Kvarnbäck, O. 2011. Density and reproductive success of Skylarks Alauda arvensis on organic farms - an experiment with unsown Skylark plots on autumn sawn cereals. Ornis Svecia 21: 3-10.

Buckingham, D.L., Giovannini, P. \& Peach, W.J. 2015. Manipulating grass silage management to boost reproductive output of a ground-nesting farmland bird. Agriculture, Ecosystems and Environment 208: 21-28.

Davies, S. 1981. Skylarks at Gibraltar point, Lincolnshire. Ringing \& Migration, 3(3): 173-180.

Delius, J.D. 1965. A population study of skylarks Alauda arvensis. Ibis 107: 466-492.

Donald, P.F. 2004. The Skylark. London.

Donald, P.F. \& Vickery, J.A. 2000. The importance of cereal fields for breeding and wintering skylarks Alauda arvensis in the UK. Pp. 140-150 in Ecology and Conservation of Farmland Birds. (Aebischer, N.J., Grice, P.V., Evans, A.D. \& Vickery, J.A., eds.). Tring: British Ornithologists' Union.

Hiron, M., Berg, Å., Pärt, T. 2012. Do skylarks prefer autumn sown cereals? Effects of agricultural land use, region and time in the breeding season on density. Agriculture, Ecosystems and Environment 150: 82-90.

Ginn, H.B. \& Melville, D.S. 1983. Moult in Birds. BTO guide 19, Tring.

Jenny, M. 1990. Territorialität und Brutbiologie der Feldlerche Aluanda arvensis in einer intensiv genutzten Agrarlandschaft. Journal für Ornithologie 131: 241-265.

Jordbruksverket. Jordbruket $i$ siffror: https://jordbruketisiffror.wordpress.com/2014/05/15/sahar-anvands-akermarken-i-ar/

Menz, M.H.M. 2008. Ecological requirements of the threatened Ortolan bunting Emberiza hortulana intemperate Europe (Swiss Alps) and in the Mediterranean (Catalonia). Masterarbeit.

Morris, A.J., Holland, J.M., Smith, B. \& Jones, N.E. 2004. Sustainable Arable Farming for an Improved Environment (SAFFIE): managing winter wheat sward structure for Skylarks Alauda arvensis. Ibis 146: 155-162.

Morris, A.J. \& Gilroy, J.J. 2008. Close to the edge: predation risks for two declining Farmland passerines. Ibis 150: (Suppl. 1), 168-177.

Odderskær, P., Prang, A., Poulsen, J.G., Andersen, P.N. \& Elmegaard, N. 1997.

Skylark (Alauda arvensis) utilisation of micro-habitats in spring barley fields. Agriculture, Ecosystems \& Environment 62: 21-29.

Ottosson, U., Ottvall, R., Elmberg, J., Green, M., Gustafsson, R., Haas, R., Holmqvist, N., Lindström, Å., Nilsson, I., Svensson, M., Svensson, S. \& Tjernberg, M. 2012. Fåglarna i Sverige - antal och förekomst. SOF, Halmstad.

Perrins, C.M. 1970. The timing of birds' breeding seasons. Ibis 112: 242-255.

Piha, M., Pakkala, T \& Tiainen, J. 2003. Habitat preferences of the Skylark Alauda arvensis in southern Finland. Ornis Fennica 80(3): 97-110.

Praus, L. \& Weidinger. K. 2010. Predators and nest success of Sky Larks Alauda arvensis in large arable fields in the Czech Republic. Bird Study 57: 525-530.

RSPB leaflet: http://www.rspb.org.uk/images/skylarkplot_ tcm9-132769.pd

Schön, M. 2011. Long-lived sustainable microhabitat structures in arable ecosystems, and Skylarks (Alauda arvensis). Journal of Nature Conservation 19: 143-147.

Smith, B., Holland, J., Jones, N., Moreby, S., Morris, A.J., Southway, S. 2009. Enhancing invertebrate food resources for skylarks in cereal ecosystems: how useful are in-crop agri-environment scheme management options? Journal of Applied Ecology 46: 692-702.

Sondell, J. 1987. Fyra trastarters ruggning vid Kvismaren. Vår Fågelvärld 46: 54-63.

Sondell, J. 1993. Moult strategies of White Wagtail Motacilla alba and Yellow Wagtail M. flava in central Sweden. Ornis Svecica 3(3-4): 107-116.

Sondell, J. 2000. Wing moult duration for the Reed Bunting Emberiza schoeniclus at Kvismaren, central Sweden, with regard to data representativeness and weather influence. Ornis Svecica 10: 13-23.

Sondell, J. \& Nielsen, B. 2005. Ruggning hos gamla svartvita flugsnappare (with English summary). Fåglar $i$ Kvismaren 31: 7-11.

Sondell, J. \& Schilt, E.-B. 1985. Bofinkens ruggning i Kvismaren. Verksamheten vid Kvismare Fågelstation 1984, sid. $2-8$.

Sondell, J., Murray, J., Persson, M. 2016. Is early grass harvest for silage an overlooked reason for skylark population declines in Sweden? Ornis Svecica 26: 89-120.

\section{Sammanfattning}

Inledning och syfte

Sånglärkan är Sveriges tjugonde vanligaste art och den största förekomsten finns i de stora slättbygderna. Även om arten är vanlig så visar inventeringar att den minskat under flera decennier. Från England har rapporterats att arten inte trivs i höstsäd eftersom den är för tät för födosök och numera sås över stora sammanhängande arealer. År 2015 genomfördes studier i Kvismaren som visade på en relativt tät lärkstam (ca 80 par per kvadratkilometer) men också på att alla lärkor som häckade i vallodlingar fick sina bon förstörda av den tidiga höskörden. I vårsäden verkade häckningarna förlöpa normalt. Frågan om återstod var hur det gick med 
häckningarna i höstsäd i Sverige representerade av området runt Kvismaren.

Syftet med lärkstudierna 2016 i Kvismaren var alltså att undersöka hur häckningarna lyckades i höstsäd. Har vi samma problem som i England? Intressant var att se hur långt sånglärkorna tvingades flyga för att finna föda och om det var någon principiell skillnad i höst- och vårsäd. En 2012 genomförd studie av tillgången på ryggradslösa markdjur, som är del av födotillgången för lärkorna redovisas också här.

\section{Studieförutsättningar}

Kvismardalen är en sammanhållen slättbygd ca 15 km SO Örebro. Via Google earth lokaliserades det största tillgängliga höstvetesfältet i Kvismardalen. Det var beläget på Mörby egendom mellan Asker och Odensbacken (Figur 1). Fältet var på 40 hektar $(450 \times 900 \mathrm{~m})$ och valdes för att studera på hur långt håll lärkorna kunde söka föda. Fältet visade sig vara bland de större i landet, vilket framgick vid ett kartsök som genomfördes i övriga slättbygder. Det stora vetefältet $i$ Mörby var omgivet av vårsädesfält och gränsade i söder till länshuvudväg 52. Fältet var homogent och enformigheten bröts bara av ett enda träd och fem rensbrunnar, markerade med käppar (Figur 3).

Fältet hade hösten 2015 såtts med en Väderstad Combi Rapid såmaskin, märket är marknadsledande. På fältet gjordes vid sådden två traktorspår på 24 meters avstånd genom att $2+2$ rader inte såddes. Traktorn skulle sedan följa dessa spår nästa vår och navigerade då med hjälp av GPS och med RTX-stöd (markkorrektion). På så sätt erhölls raka sårader som traktorn också kunde följa hela växtperioden 2016. Två gånger två sårader stängdes av (teoretiskt $0,375 \mathrm{~m}$ per hjul) för att erhålla osådda spår åt traktorn som hade $0,3 \mathrm{~m}$ breda däck (Figur 2). Fältet sprutades med biocider två gånger och gödslades med fyra mindre givor för att gödsel inte skulle lakas ut till grundvattnet.

\section{Studiemetodik}

För orientering sattes stakkäppar upp längs fältets östra och norra kant. Därtill fanns de fem brunnarna för vattenreglering på olika avstånd (Figur 2). Från tre plattformar skapades bra utsikt över fältet (Figur 3). Totalt 80 mantimmar spenderades på att följa lärkorna. Studien utfördes perioden 30 maj till 19 juni då matning av ungar pågick i stor omfattning. Höjden på sädesstråna mättes tio gånger under juni månad. Sädens stråhöjd ökade från 0,45 m den 30 maj, 0,75 m 13 juni, $0.8 \mathrm{~m} 19$ juni och till nästan $0,9 \mathrm{~m}$ den 30 juni. Vid observationerna var det viktigast att bedöma matningsaktiviteten och notera bonas lägen, längden på födosöksrundorna och i vilken typ av vegetation lärkorna sökte föda. Varje observationsdag (17 av 21 tillgängliga dagar, 80 mantimmar) sökte observatörerna slumpvis upp ett eller flera lärkbon med stor aktivitet och noterade var på åkern boet låg (exakt riktning med tub och bedömt avstånd). Efter tre matningar och därpå följande uppflog var detta i regel fastställt. Sedan registrerades födosök om något av följande tre kriterier var uppfyllt:

Komplett fördosöksrunda inkluderande att lärkan lyfte från boet, landade i födosöksområdet och återvände till boet med föda.

Lärkan lyfter från boet och landar i födosöksområdet eller försvinner långt bort. Detta gällde mestadels på långa håll.

Lärkan kommer flygande från födosöksområdet och landar vid boet. Detta hände oftast på kortare avstånd.

Sex bon besöktes för att konstatera häckningsutfallet. Studierna avslutades med ett eftersök av var lärkorna höll till i området den 23 juni, då häckningen bedömdes vara i stort sett avslutad. En promenad längs traktorspåren $i$ båda fälten företogs, totalt ca $35 \mathrm{~km}$ (2 observatörer gick vardera 17,5 $\mathrm{km})$.

Redan 2012 gjordes en studie för att studera i vilka habitat det fanns mest ryggradslösa djur som kunde vara lämpliga som föda för bl.a. sånglärka. Fem fällor i form av plastglas grävdes mer i fem biotoper: osått fält (träda), osådd kant längs fält med vårsäd, på kanten av grusväg, i havrefält samt i potatisfält. Tre fångstomgångar genomfördes i varje biotop i maj-juni.

Den 1 augusti gjordes en $500 \mathrm{~km}$ lång biltur genom Mellansverige för att undersöka frekvensen traktorspår $\mathrm{i}$ åkrarna. Alla åkrar intill vägen kontrollerades. Skörden av höstvete skulle just starta.

\section{Resultat}

Antalet observerade födosök redovisas i tabell 1 . Totalt har 84 matningar registrerats från 61 platser, 27 inom höstsädesfältet och 22 utanför i vårsäd. Därtill kommer 2 på grusvägen och $10 \mathrm{i}$ gräs på en körväg mellan åkrarna. Alltså var 45 procent av födosöket inom häckningsfältet, 35 utanför och 20 längs vägarna i kanten av studiefältet. Avståndet var i medeltal minst $204 \mathrm{~m}$. 22\% bedömdes till längre än $300 \mathrm{~m}$ och det längsta till $550 \mathrm{~m}$. Efter den 13 juni då vetestråna nått $0,75 \mathrm{~m}$ sågs en 
ökande andel av lärkorna i vetefältet hålla till i och omkring traktorspåren (Figur 5).

Fördelningen av bon på studiefältet framgår av Figur 2. Troligen var ca 20 bon föremål för våra studier under en eller flera dagar. Bona är utspridda över hela fältet utan tydliga aggregeringar i någon del. Vi kontrollerade 6 bon varav tre låg i höstsäd och tre $i$ vårsäd intill. Utifrån våra stickprov av bobesök bedömde vi att bona utvecklades normalt.

Många lärkor noterades använda traktorspåren för födosök, vila och dold väg till boet. I början av matningsperioden var det svårare att se hur lärkorna rörde sig i fältet i förhållande till spåren. När stråna blev högre blev det lättare och den sista veckan blev spåren allt viktigare. Vid inventeringen den 23 juni stöttes alla lärkor från traktorspår, men eftersom traktorspåren användes för att gå genom fältet, finns det en möjlighet att lärkor kan ha undgått att stötas om de befunnit sig utanför spåren. Studien resulterade i att 5 lärkor flög upp ur höstsäden och 8 ur den närliggande vårsäden. Dessutom sågs 10-13 lärkor i luften över vartdera fältet.

Traktorn gjorde sex överfarter, två för sprutning och fyra för gödsling vilket gjorde att spåren hölls uppkörda (Figur 4). Förutom i spåren hittades små öppna ytor i närheten av bona (Appendix 1).

Fångade ryggradslösa djur redovisas i tabell 1. Där framgår att det fanns ungefär lika stora mängder potentiella bytesdjur oberoende av typ av markunderlag på Kvismarslätten.

Häcknings- och ruggningsperiod redovisas i Figur 6. En häckningscykel täcker ca 45 dagar inklusive bobyggnad. Via ringmärkningsdata går det att ungefärligt härleda lärkornas häckningsstart i mellersta Sverige. Efter 26 dagar är nämligen lärkungarna märkstora (6 dagar). Häckstart sker alltså ca 1 maj. Om en andrakull läggs kan den i medeltal startas tidigast 15 juni och vara klar 30 juli. Troligare är att en ersättningskull läggs om förstakullen misslyckas (Figur 6).

Ruggningen av sånglärkans handpennor tar $\mathrm{i}$ England 58-60 dagar och startar direkt efter det att häckningen är avslutad. Från Sverige finns inga ruggningsdata men för gulsparven, som finns i ungefär samma biotop har vi fina data. Gulsparven ruggar lika fort som sånglärkan $\mathrm{i}$ England och $\mathrm{i}$ Kvismaren tar hela vingruggningen (handpennor och armpennor) 67 dagar i medeltal. Gulsparven startar rugga i medeltal 18 juli och är klar 25 september. Bara en mindre del av gulsparvarna bedöms alltså teoretiskt kunna starta en ren andrakull. Tidsschemat överensstämmer sannolikt med sånglärkans.

Tänkbara predatorer observerades i begränsad omfattning. Vanligast var kråka och brun kärrhök. En kärrhök sågs vid ett tillfälle jaga en sånglärka utan framgång.

Studien från bil längs huvudvägar i mellersta Sverige för att bedöma frekvensen traktorspår i sädesfälten visade att ca tre fjärdedelar hade traktorspår. Det var fält som odlades ekologiskt men också vissa fält av vårsäd av havre och korn som saknade spår.

\section{Diskussion}

Sånglärkan dominerar den öppna slätten och avskyr skog. Den är en utmärkt flygare och kan på våren hävda revir sjungande $\mathrm{i}$ luften under många timmar varje dag. Vid studier i Kvismaren 2015 visade det sig att häckningar i vallodling förstördes av den tidiga ensilageskörden medan häckningarna i vårsäd utvecklades normalt (fyra bon kontrollerades). Från England har det kommit signaler om att höstsäden utgör ett mindre bra häckningshabitat därför att den är hög och tät och täcker stora sammanhängande åkerarealer. Åtgärder i form av lärkrutor behövs. Frågan är hur förhållandena är i Sverige.

För studien valdes ett mycket stort fält, detta för att studera på hur långt avstånd sånglärkorna kunde hämta föda. Där häckade många par sånglärka, uppskattningsvis ca 30 par. Den stora homogena ytan hindrade inte lärkorna att häcka - tvärtom! Vi noterade att $300 \mathrm{~m}$ provianteringsavstånd var normalt och i vissa fall flög lärkorna en halv kilometer. Lärkorna sökte dock föda inom och utom fältet i ungefär samma utsträckning. När säden blev högre koncentrerades födosöket till traktorspåren där marken fortfarande var åtkomlig och relativt öppen (Figur 2). Spåren utgjorde 2,5\% av den totala arealen av det studerade fältet.

Vår studie av ryggradslösa smådjur visade att dessa, som potentiell föda, förekom ungefär lika talrikt över hel jordbruksmarken. Frågan är alltså inte främst tillgången till bytesdjur utan om dessa är åtkomliga för lärkorna eller inte. I kortare vegetation som traktorspår och vägkanter är det givetvis lättare att hitta föda.

Tidsåtgången för häckning och ruggning är schemalagd. Eftersom en häckningscykel tar 45 dagar och först kommer igång omkring 1 maj och ruggningen troligen tar ca 67 dagar är det osannolikt att sånglärkan normalt genomför två häckningar inom studieområdet. Däremot hinns troligen ofta en omläggning med om boet prederas (Figur 6). Sånglärkans aktivitet på fälten går också enligt våra observationer snabbt ner $i$ slutet $a v$ juni. Vid 
inventeringen 23 juni sjöng inga revirhävdande sånglärkor. De fåglar som häckar i höstsäd kan genomföra häckningen minst 1-2 veckor tidigare än paren i vårsäd. Att få ungarna tidigt flygga är alltid en stor fördel för mindre tättingar.

Möjligheten att lämna osådda traktorspår har funnit i ca 30 år i Sverige. Sådana osådda traktorspår erbjuder lärkorna fem gånger så stor areal öppen jord (eller låg vegetation) på sädesfälten jämfört med anlagda lärkrutor. Dock finns idag inga publicerade svenska data på häckningsframgång för sånglärkor i höstsäd med lärkrutor jämfört med enbart traktorspår. Jag anser att sånglärkan bäst skulle gynnas genom att försöka minska förlusterna vid tidig skörd av vallodlingarna. Hur detta bör gå till måste studeras vidare. 


\section{Appendix 1}

Location of two Skylark nests in 2016 at Mörby, Kvismaren valley

This Appendix was written by Lei Stanley Tang

In June 2016 I have found three nests of the Skylark in autumn crop at Mörby. All three nests were well hidden at the root stems of the crop (wheat), surrounded by tall stalks. Very close $(0.1-0.5 \mathrm{~m})$ to each nest, I found small patches of openings which were on average at 0.5-1.0 meter in diameter. Droppings from the adults were easily visible at two of the three nests (Figure 7). During the feeding observations we noticed that adult skylarks usually land at locations nearby the nest and lift straight from the nest after feeding the chicks (Donald 2004). Consequently, I suspect that the observed open patches near the nests were used as landing platforms or roosting sites. It is also possible that the larks used the ground patches to prepare (kill) caterpillars or larvae before offering them to the young. In addition, the openings may also be used as navigation landmarks for the adults to find their nests through the homogeneous field.
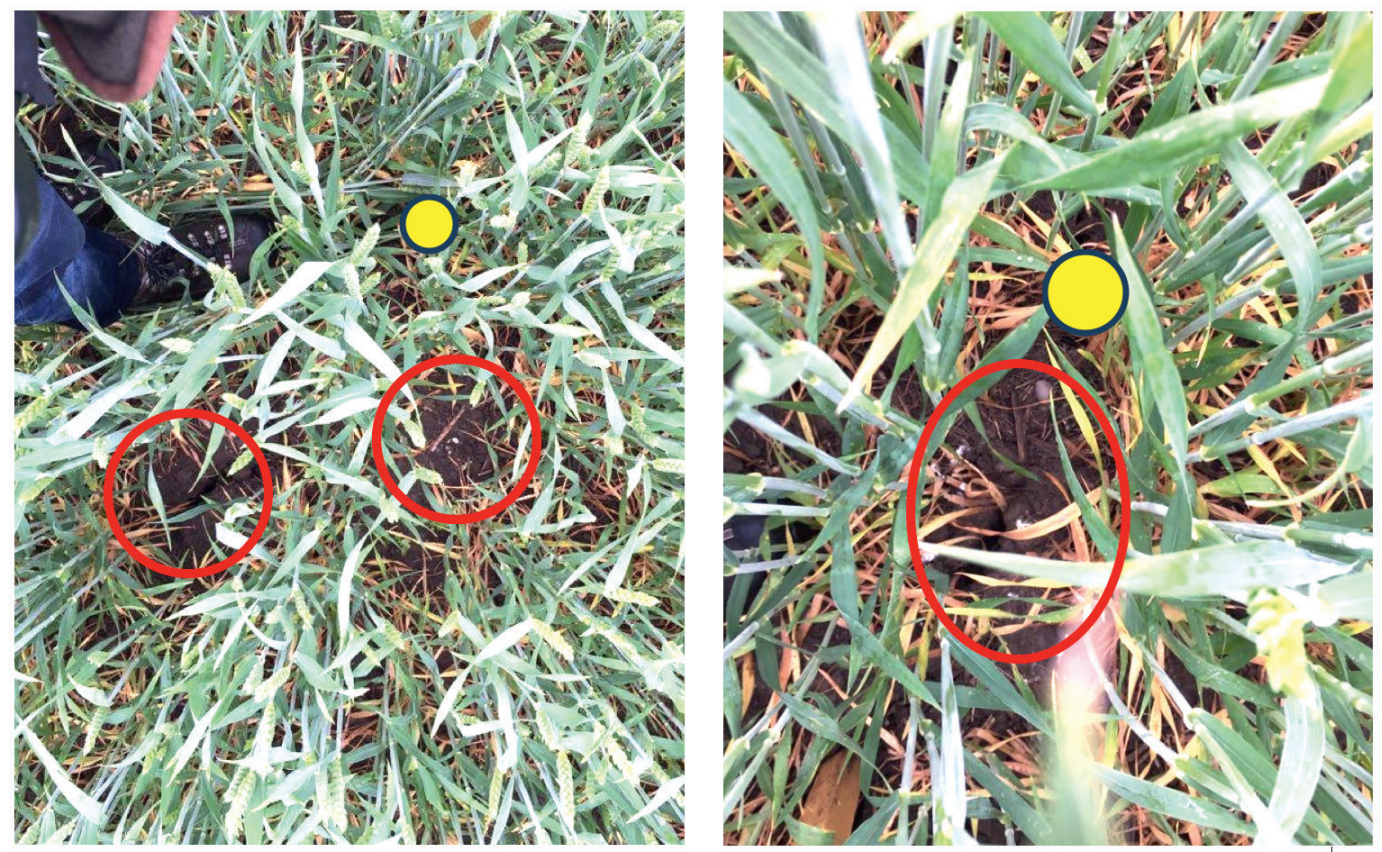

Figure 7. Photos showing open patches observed near two of the skylark nests. Yellow dots indicate the nest locations and its size and red circles mark the open patches.

Foton som visar öppna fläckar intill två bon av sånglärka. Gula fläckar indikerar bon och röda cirklar öppna fläckar. 


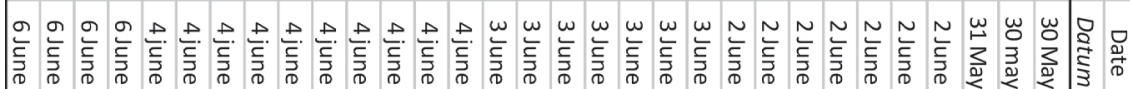

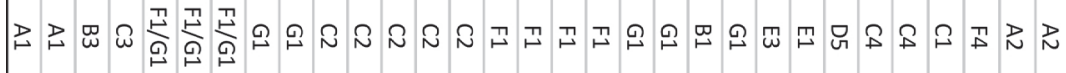

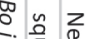

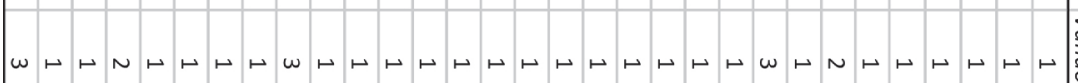

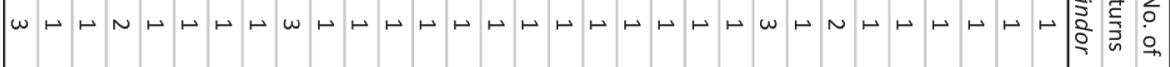

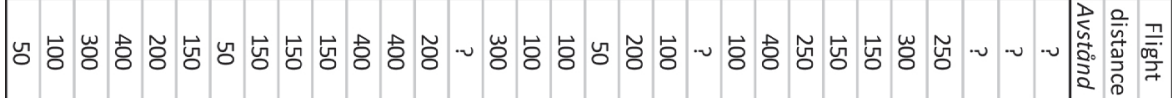

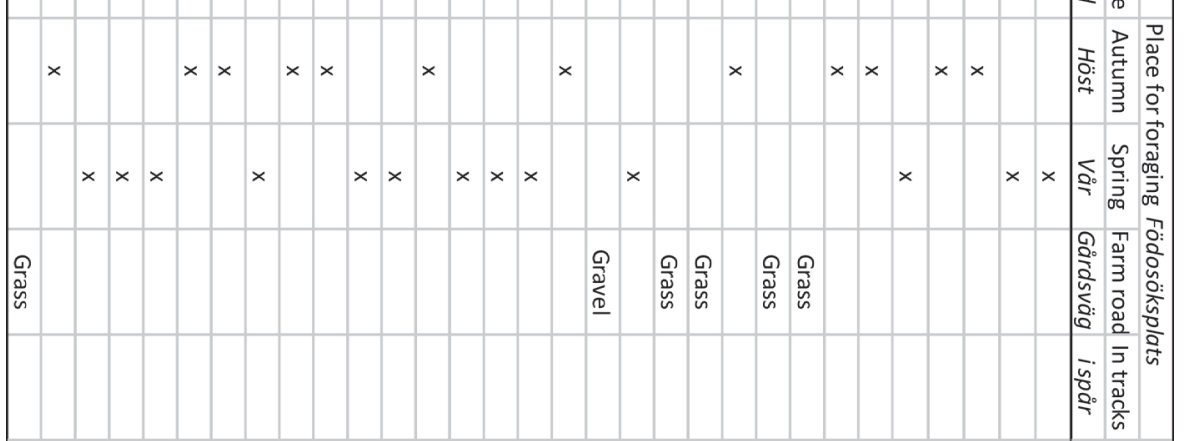

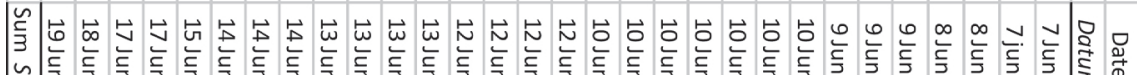

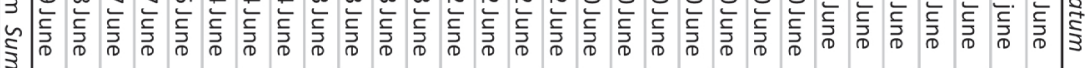

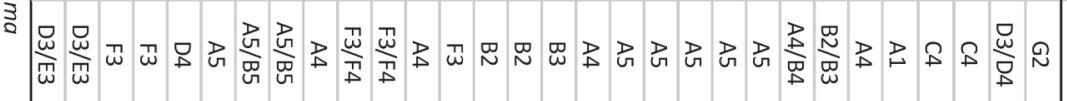

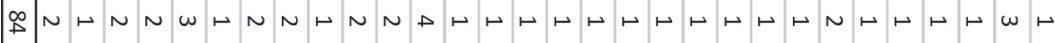

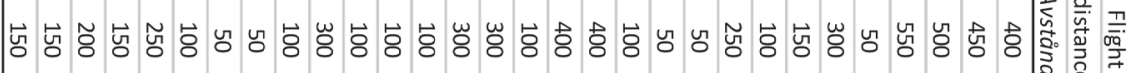

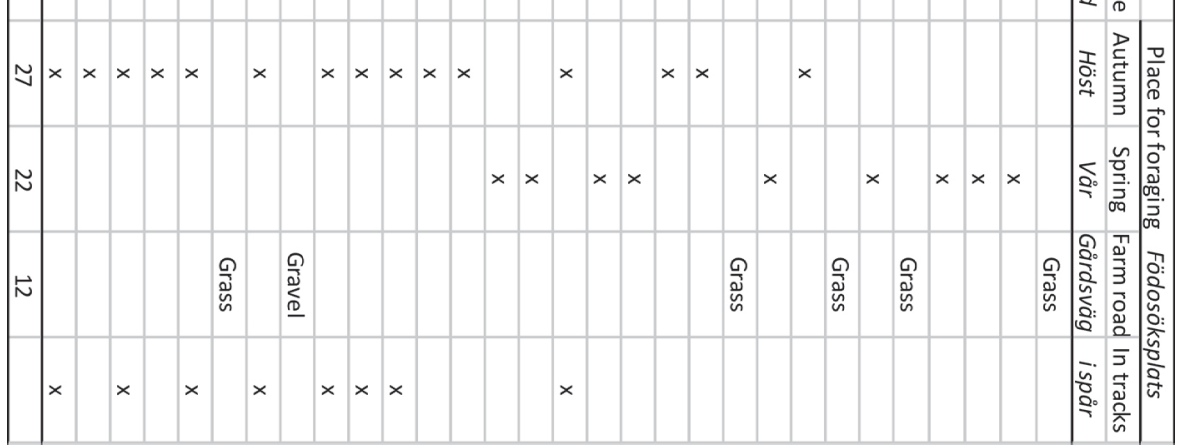

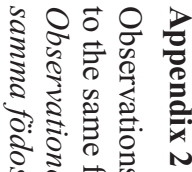

क.

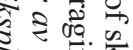

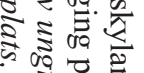

ठ월

类

क

क: ₹

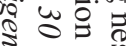

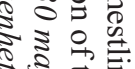

3.1.

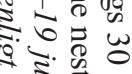

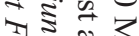

og $\sim$ กै

는은

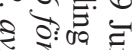

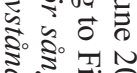

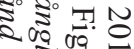

₹

충

3

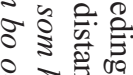

इ ₹: है

के है ह

这.

ㅇ: .

की:

今

융

o:

के

: 3

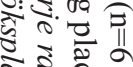

훙

क्ज उ

원용

휴

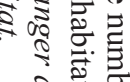

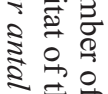

룽요

눙요

s

จ물

눌

郎焉. 